\title{
The Development of Interactive Computer-Based Learning Models to Improve Student Learning Outcomes in Integrated Social Studies Education at SMP Negeri 4 Tarutung
}

\author{
Wesli H Situmeang ${ }^{1}$, Sahat Siagian ${ }^{2}$, Efendi Napitupulu ${ }^{3}$ \\ \{wesli.h.situmeang@gmail.com $\}^{1}$ \\ Universitas Negeri Medan, Medan, Indonesia ${ }^{1,2,3}$
}

\begin{abstract}
This study aims to: produce visual based learning media products that are appropriate to use, easy to learn by students and can be used for early childhood. This type of research develops the ADDIE model from the Dick and Carey learning design model. The results showed: (1) the expert test material qualifications were very good (89\%), (2) the learning design expert qualifications were very good (97\%), (3) the instructor learning media qualification test was very good $(89 \%)$, (4) individual qualification trials are very good $(95.16 \%)$, (5) small group trials with very good qualifications $(96.01 \%)$, (6) field trials are limited to very good qualifications $(96.12 \%)$, and suitable for use in the learning process early on. Hypothesis testing results prove that there are significant differences between student learning outcomes that are learned using media products with student learning outcomes that are learned without using media products. This is indicated by the results of data processing obtained by $\mathrm{t}$-count $=3.678>\mathrm{t}$ table $=1.79$, with $\mathrm{dk}=2$ at the significance level $\alpha=0.05$. It was concluded that the learning outcomes of students taught using interactive computer-based "Wesli" learning models was $83 \%$ higher than the group of students taught without 81 learning media products.
\end{abstract}

Keywords: Computer Based Learning, Social Studies, ADDIE Model

\section{Introduction}

With the development of technology at this time where students are able to follow technology in daily life, where learning models are required to evolve according to technological developments, the low student learning outcomes in Integrated Social Studies learning and learning methods that are still teacher-cantered and the opportunities for information technology development and communication in learning it is necessary to innovate student-oriented learning and facilitate learning needs that are challenging, Active, Creative, Effective and Enjoyable (PAIKEM) to prepare students to face future challenges with the development of information technology and global competition, one of which is by developing models learning and integrating the learning process with interactive computer-based learning.

Researchers are interested in developing the WESLI learning model (Weakness, Explicit Instruction, SAVI, LAPS Heuristics, and Introspection). Based on computers using Microsoft Power Point application for presentations and designed for interactive activities using the 
Ispring Suite program so that it is expected to have a two-way relationship between computers (software / applications / products) with students, components of the WESLI learning model:

Weakness: giving questions or problems (a case relating to learning material) to students so that we know where lies the weaknesses of each student from the way he answered the case. Explicit Instruction that is the results of student answers that may be less satisfactory, the teacher demonstrates pictures and videos using the Microsoft Power Point learning application so that students understand the material

SAVI (Somatic, Auditory, Visual and Intellectual) by demonstrating learning using the Microsoft Power Point application, students make use of all student senses so that the material can be digested LAPS Heuristics (Logan Avenue Problem Solving) in a series of questions that are demands that provide cases and provide instructions on how to answer questions using the Microsoft Power Point application, with the questions students look for answers and be able to answer questions and master the subject matter.

Introspection, in this case the teacher evaluates the results of the answers that have been submitted by students and gives an assessment to students. The use of learning models by using computers with interactive power point applications allows students to adjust the speed in mastering the lesson. A student who has a higher learning speed will more quickly complete his learning activities while students who have a slow learning speed will complete their activities in accordance with their respective abilities so that the student is able to follow, In contrast to the direct learning method which is generally the speed of understanding learning is determined by the teacher. It is apparent that learning media is very influential in the effectiveness and efficiency of learning.

\section{Research Methods}

The method used in this research is ADDIE development research. The subject in this research is the material "Social Interaction" contained in the RPP (Learning Program Plan). This research is conducted to SMPN 4 Tarutung students who are studying "Social Interaction" learning material. Data obtained by giving questionnaires and objective tests of learning outcomes. The data obtained were then tested for normality and homogeneity. This research hypothesis will be tested using T-test analysis (t-test).

\section{Results and Discussion}

Data obtained Based on the results of the assessment of learning material experts that the learning model using interactive computers in the material Social interaction has the feasibility of three aspects of assessment which includes aspects of the feasibility of the material with a percentage score of $89 \%$, the feasibility aspects of learning design $97 \%$. The feasibility aspect of software engineering is $87.5 \%$. It shows that the learning model using an interactive computer that is developed can meet the demands of learning needs.

Table 1. Average Percentage of Assessment Results by Material Experts

\begin{tabular}{lcl}
\hline Indicator & Rating Percentage & Criteria \\
\hline Content eligibility & 88 & Very feasible \\
Presentation & 90 & Very feasible
\end{tabular}




\begin{tabular}{|c|c|c|}
\hline Linguistic & 75 & Very feasible \\
\hline Finesse & 88. & Very feasible \\
\hline Total & 89 & Very feasible \\
\hline
\end{tabular}

Table 2. Percentage Average Assessment of Learning Design Experts

\begin{tabular}{lcc}
\hline Indicator & Rating Percentage & Criteria \\
\hline Quality of Information Design & 100 & Very feasible \\
Quality design information & 92 & Very feasible \\
Quality of interaction & 100 & Very feasible \\
Presentation quality & 96 & Very feasible \\
\hline Total & 97 & Very feasible \\
\hline
\end{tabular}

Table 3. Percentage of Average Assessment from learning media expert

\begin{tabular}{|c|c|c|}
\hline Indicator & Rating Percentage & Criteria \\
\hline Programming & 75 & Very feasible \\
\hline $\begin{array}{lr}\text { Graphic / } & \text { technical } \\
\text { appearance } & \text { and } \\
\text { interaction } & \end{array}$ & 86 & Very feasible \\
\hline Total & 87 & Very feasible \\
\hline
\end{tabular}

Furthermore, the data obtained in this study are the results of early childhood learning in SMPN 4 Tarutung with the material "Social Interaction". Based on the results of the study it can be seen that the learning outcomes of the minimum, maximum, average and early childhood standards in the Learning Model development group using Interactive computers.

Table 4. Minimum Learning Outcomes, Maximum and Standard Deviation in SMP N 4 Tarutung

\begin{tabular}{lcccc}
\hline Learning Outcomes & Min. & Max. & Mean & Std. Deviation \\
\hline Pre Media Development & 44 & 75 & 78.5 & 4.663 \\
Post Media Development & 47 & 100 & 78.22 & 16.84 \\
\hline
\end{tabular}

Based on Table 4, it can be seen that the learning outcomes in SMP 4 Tarutung in the intervention group minimum learning outcomes after given the development of learning models increased from 40 to 47 , the maximum learning outcomes after the intervention in the development of learning media has increased from 60 to 100 and on average (average) learning outcomes after being given the development of interactive computer-based learning models have increased from 70 to 83 after the experiment.

Learning outcomes data are then subjected to analysis prerequisite tests which include tests of normality and homogeneity tests. Normality test conducted on learning outcome data in this study is the Liliefors test. The normality of data is significant if the test results $1>0.05$. The results of the normality of the pretest and posttest data can be seen in Table 5

Table 5. Data Normality Test for Experiment Class and Control Class

\begin{tabular}{lccc}
\hline Data & Class & $\boldsymbol{l}$-count & $\boldsymbol{l}$-table \\
\hline Pretest & Experiment & 0.1566 & 1.796 \\
Posttest & Experiment & 0.1566 & 1.833 \\
Pretest & Control & 0.1366 & 1.833 \\
\hline
\end{tabular}




\begin{tabular}{llll}
\hline Posttest & Control & 0.1366 & 1.833 \\
\hline
\end{tabular}

Based on the results of normality testing in the experimental class and the control class in Table 5, it is known that the pretest and posttest data in both classes produce a normality test value $(l)>0.05$. Thus, it can be concluded that learning outcomes data in the experimental class and the control class are normally distributed. Homogeneity test conducted in this study uses the Lavene Equality of Error Variances Test. Homogeneity of data is fulfilled if the significance test results obtained $>0.05$. Homogeneity test results of pretest and posttest data can be seen in Table 6.

Table 6. Test Homogeneity of Pretest and Posttest Data

\begin{tabular}{lccc}
\hline Data & Class & p-value & A \\
\hline Pretest & $\begin{array}{c}\text { experiment } \\
\text { control } \\
\text { Posttest }\end{array}$ & 1.56 & 1,79 \\
& $\begin{array}{c}\text { experiment } \\
\text { control }\end{array}$ & 1.79 & 1,79 \\
\hline
\end{tabular}

Based on the results of homogeneity testing in the experimental and control classes in Table 6 , the results of the pretest and posttest significance were obtained $>0.05$. Thus, it can be concluded that the pretest and posttest learning outcome data in the experimental class and the control class are homogeneous.

After the analysis prerequisite tests are fulfilled, the learning outcomes data are analyzed to test the research hypotheses. Hypothesis testing is done by the $t$ test formula. Based on the calculation results obtained tcount $<$ ttable $=1.79$. Based on these results, Ho and ha are accepted or in other words there is a significant difference between learning outcomes in the experimental class and the control class at the 5\% significance level. Thus, learning outcomes "Social interaction" taught by the development of computer-based learning models are different from the learning outcomes tested.

The test of development of interactive computer-based learning models it was found that the results of the T-test statistic obtained tcount (3.678)> ttable (1,79), meaning that Ho was rejected, meaning that the development of interactive computer-based learning models was effective for improving student learning outcomes at SMP N 4 Tarutung.

\section{Discussion of Product Development Results}

Development of interactive computer-based learning models based on the stages as stated in the procedure. The results of further development are carried out due to due diligence or validation by predetermined experts. Based on the results of the validation, the product in the interactive computer-based learning model "Social Interaction" was declared very feasible to be continued in the field trials. The learning media developed have met the standards based on the design standards of instructional media development and learning material standards.

The product development research carried out is directed to produce products in the form of computer-based interactive learning models in the material "Social Interaction" at SMP N 4 Tarutung which are used to improve student learning outcomes. Aspects are revised and refined based on data analysis and tested and input from material experts, learning design experts, instructional media experts. It aims to explore some aspects that are common in the process of developing a product. 
The results of the assessment presented by material experts about the development of a computer-based interactive learning model "Social Interaction" gave an average percentage of $93.13 \%$, so that the learning media included in the "very feasible" category so that it could be accepted and suitable for use in the learning process. The results of the assessment of learning design experts in the development of computer-based learning development models with an average percentage score of $93.13 \%$. and meet learning design standards. Meanwhile, learning media experts in learning media gradually developed a computer-based interactive learning model, giving an average percentage of $93.75 \%$, so that the development of visual-based learning media using a computer-based interactive learning model Social Interaction "included in the" very feasible "category so it is acceptable and suitable for use because it contains materials and shipping criteria that meet the message delivery requirements.

From the discussion above it can be concluded that the development of a computer-based interactive learning model "Social Interaction" is feasible for learning as a learning in SMPN 4 Tarutung

\section{Discussion of Research Results of Product Effectiveness Test}

Based on statistical tests that have been done, the results of hypothesis test analysis are obtained, namely $\mathrm{t}$-count $=3.678$ and $\mathrm{t}$-table $=1.79$ which is $\mathrm{t}$-count $>\mathrm{t}$-table, this means the use of interactive computer-based learning model media can improve initial learning outcomes at Tarutung Middle School 4 subjects, with an influence on improving learning outcomes by $41.17 \%$. Interactive computer-based learning models improve learning outcomes because students actively use all five senses to solve the problems made in computers so that students can follow learning according to their abilities so that students can master the material perfectly

\section{Conclusions}

Based on the results of research that has been done and the results of data analysis obtained can be concluded as follows. Based on statistical tests that have been done, the results of hypothesis test analysis are obtained, namely $\mathrm{t}$-count $=3.978$ and $\mathrm{t}$-table $=1.79$ which is $\mathrm{t}$ count $>$ t-table, this means the use of interactive computer-based learning model media can improve initial learning outcomes at Tarutung Middle School 4 subjects, with an influence on improving learning outcomes by $41.17 \%$.

The results showed that the development of computer based "Wesli" learning models had a positive effect in creating an active and enjoyable learning process. The development of visual snake game media has proven to make students more enthusiastic and responsible for more active learning, which in turn has an impact on student learning outcomes better than without using media. Therefore, the development of interactive computer-based learning models can be recommended for use in the student learning process. Suggestions that can be given to teachers, so that they can implement interactive computer-based learning models by planning better learning, so that the results obtained are more optimal and efficient.

\section{References}

[1] Dick, Carey. The systematic Design of Instructional sixth edition. USA : Pearson Allyn 
and Bacon (2005).

[2] Sugiyono. Metode Penilitian Pendidikan. Bandung: Alfabeta (2005).

[3] Winkel, W.S. Psikologi Pengajaran. Jakarta: Gramedia.Santrock, John W. Life-span Development : Perkembangan Masa Hidup. Edisi 5 jilid 2, Jakarta : Erlangga (2002).

[4] Sriadhi, et al. Internet-based social media and its influence on student behaviour changes. IOP Conf. Series: Materials Science and Engineering 434 (2018) 012267 doi:10.1088/1757-899X/434/1/012267

[5] Smaldino, Sharon E, Et. Al. Instructional Technology Media for Learning. Pearson Education. Inc (2012). 